\title{
Quality Assessment of Selected Ground Water Sources Around a University Teaching Hospital Liquid Waste Treatment Plant
}

Elijah Abakpa Adegbe ( $\square$ abakpa30@gmail.com )

National Research Institute for Chemical Technology Zaria

Lois Riyo Maina

Department of Chemistry Ahmadu Bello University Zaria

Shola Elijah Adeniji

Department of Chemistry Ahmadu Bello University Zaria

Opeoluwa Olusola Fasanya

National Research Institute for Chemical Technology Zaria

Stanley Irobekhian Reuben Okoduwa

Nigerian Institute of Leather and Science Technology, Zaria Nigeria.

\section{Research Article}

Keywords: Groundwater, Effluents, Heavy metals, Physicochemical parameters, Lead, Iron

Posted Date: April 6th, 2021

DOI: https://doi.org/10.21203/rs.3.rs-399489/v1

License: @ (i) This work is licensed under a Creative Commons Attribution 4.0 International License. Read Full License 


\section{Abstract}

Background:The study conducted a comprehensive assessment of the quality of selected groundwater sources around the liquid waste treatment plant of Ahmadu University Teaching Hospital Shika, Nigeria. Water samples were collected from four (4) hand-dug wells following standard procedures, ten (10) physicochemical parameters and seven (7) heavy metals were analyzed.

Results: All the physicochemical parameters studied were within the WHO specified limits except for DO which was less and turbidity which was higher. Heavy metals were found in the all the groundwater sources that were studied. However, the concentration of some heavy metals exceeded the specified limits recommended by the World Health Organization (WHO). The heavy metal presence in the groundwater sources may be connected to human activities such as waste disposal containing these metals around the groundwater sources and liquid waste from the hospital which can may have seeped into the wells.

Conclusion: By implication, this study shows that the hand-dug wells were not safe for drinking. It is recommended that wells be sited away from dumpsites and waste treatment plants and effluents from waste treatment plants should also be properly treated before their subsequent discharge into the environment. This study has generated a baseline data that will be useful in monitoring heavy metal pollution.

\section{Background}

Water is a necessity for the sustenance of a healthy life (Abubakar, 2018). The provision of good drinking water is becoming a huge task for the government, decision making bodies and institutions spearheading water management in nations with the increasing populace (Abubakar, 2019). Good drinking water relates to water protected from external contamination and is required for healthy living (Owamah et al, 2020; Abubakar, 2018).

In 2015, only $24 \%$ of the 319 million dwellers of sub-Saharan Africa had access to good drinking water (Owamah et al, 2020) in contrast to Latin America and the Caribbean (65\%), West Asia and North Africa (90\%), East Asia and Southeast Asia (94\%) respectively.

Nigeria, one of the countries of sub-Saharan Africa was reported in 2015 to have provided $67 \%$ of its population access to water free of contamination. However, it is still below the 77\% MDG target and the global mean of 91\% (UNICEF/WHO, 2015, p.9). In 2013, reports obtained from Nigeria Demographic and Health Surveys revealed that $50.8 \%$ of rural dwellers and $14.4 \%$ of urban dwellers in Nigeria use drinking water from sources that are not safe (Abubakar, 2019). Studies conducted in Nigeria revealed that several water sources are contaminated (Bamgboye et al 2020; Ibe et al 2020; Oyelami et al 2013; Zacchaeus et al 2020). However, it is sad to note that in Nigeria and many other developing nations, water consumption is from these unsafe sources (Owamah, 2020; WHO and UNICEF RADWQ, 2012). The consumption of contaminated water together with poor hygiene and sanitation has been revealed as the cause of more than a million death globally (WHO 2012). Reports show that the use of contaminated water sources, open defecation and poor hygiene are responsible for more the $80 \%$ of water-borne diseases in developing countries (Owamah 2020).

The population of Nigeria was estimated in 2017 to be more than 190 million (NPC, 2017). Despite this large population, Nigeria still has huge drawbacks in the provision of safe drinking to her rural dwellers and settlers in small towns (Owamah, 2020). This has created a huge dependence on groundwater sources which are not free from contamination because of human activities like open defecation, poor disposal of solid waste and inefficient sewage disposal etc (Dahunsi, 2014; Sojobi, 2016).

The quality of groundwater sources is not well documented for the Shika district of the Giwa local government area of Kaduna State. A robust database is needed to aid in the formulation of policies that will improve water quality, sanitation and eventually enhance human health. This study was carried out to ascertain the physicochemical quality and heavy metal content of some groundwater sources situated near the Ahmadu Bello University Teaching Hospital in Shika, Kaduna State, Nigeria.

\section{Methods}

\subsection{Description of study area}

This study was carried out near the liquid waste treatment plant of Ahmadu University Teaching Hospital Shika, Nigeria. The integrity of Four hand-dug wells was accessed for possible contamination. The water from these wells is employed by the rural dwellers for watering their farms and for household use. For this study, the wells were coded U1, U2, U3 and U4 correspondingly (Figure 2). 


\subsection{Sample collection and preparation}

The water samples were obtained in clean sterile bottles from the study area using standard methods for collection and preservation (APHA, 2012). The samples for physicochemical assay were preserved in ice before transportation to the Water Resources Laboratory of Ahmadu Bello University Zaria, Nigeria. They were subsequently stored in a refrigerator at $4^{\circ} \mathrm{C}$ before carrying out the laboratory procedures.

\subsection{Determination of physicochemical parameters and heavy metal content}

Water quality parameters such as electrical conductivity (EC), temperature and hydrogen ion concentration $(\mathrm{pH})$ of the samples were verified utilizing a portable HANNA, H19813-5 model. Turbidity was measured using a turbidimeter (HACH), while nitrate, phosphate, sulphate, dissolved oxygen (DO), biological oxygen demand (BOD) and Chemical oxygen demand (COD) were verified according to APHA (2012) methods. The assay of the heavy metal content was performed using the atomic absorption spectrophotometer (AAS) (AA-6800 SHIMADZU model) in line with the methods of APHA (2012).

\section{Results}

\subsection{Physicochemical levels in groundwater}

The experimental data statistics obtained for the physicochemical quality of the groundwater samples are all given in Table 1. the pH ranged from 6.30 to 7.23 . EC obtained varied from $43.00 \mu \mathrm{S} / \mathrm{cm}$ and $62.00 \mu \mathrm{S} / \mathrm{cm}$. The mean value of Dissolved oxygen (DO) obtained in this study varied from $1.13 \mathrm{mg} / \mathrm{L}$ to $1.50 \mathrm{mg} / \mathrm{L}$. The BOD values obtained varied from 0.13 to $0.50 \mathrm{mg} / \mathrm{L}$. The COD values ranged from $1.80 \mathrm{mg} / \mathrm{L}$ to $6.70 \mathrm{mg} / \mathrm{L}$. The mean turbidity values ranged from 5.70 to $7.40 \mathrm{NTU}$. Nitrate values in the range of $3.40 \mathrm{mg} / \mathrm{L}$ to $18.90 \mathrm{mg} / \mathrm{L}$ were obtained in this study. Sulphate values ranged from $1.20 \mathrm{mg} / \mathrm{L}$ to $6.90 \mathrm{mg} / \mathrm{L}$. The phosphate content varied from 0.10 $\mathrm{mg} / \mathrm{L}$ to $1.40 \mathrm{mg} / \mathrm{L}$. Temperature ranged from 25 to $27^{\circ} \mathrm{C}$. All the physicochemical parameters studied did not show a significant difference $(P<0.05)$ except for COD that varied significantly $(P<0.05)$ within the study area.

Table 1: Statistics of the levels of physicochemical parameters in groundwater

\begin{tabular}{|llllll|}
\hline Parameters & U1 & U2 & U3 & U4 & WHO (2011) \\
\hline pH & $6.80 \pm 0.02$ & $7.23 \pm 0.01$ & $7.00 \pm 0.01$ & $6.30 \pm 0.01$ & $6.5-8.5$ \\
\hline E.C $(\mu \mathrm{S} / \mathrm{cm})$ & $62.00 \pm 1.00$ & $44.00 \pm 1.00$ & $49.00 \pm 1.00$ & $43.00 \pm 1.00$ & $500-1500$ \\
\hline D.0 (mg/L) & $1.40 \pm 0.10$ & $1.13 \pm 0.10$ & $1.20 \pm 0.10$ & $1.50 \pm 0.10$ & 5 \\
\hline B.0.D (mg/L) & $0.50 \pm 0.20$ & $0.13 \pm 0.10$ & $0.13 \pm 0.10$ & $0.30 \pm .10$ & 6 \\
\hline C.0.D (mg/L) & $1.80 \pm 1.00$ & $3.50 \pm 2.00$ & $2.31 \pm 1.20$ & $6.70 \pm 2.00$ & 10 \\
\hline Turbidity (NTU) & $6.00 \pm 0.01$ & $7.40 \pm 0.01$ & $7.20 \pm 0.01$ & $5.70 \pm 0.01$ & 5 \\
\hline Nitrate (mg/L) & $3.40 \pm 0.20$ & $13.70 \pm 0.10$ & $18.90 \pm 0.10$ & $16.40 \pm 0.10$ & 50 \\
\hline Sulphate (mg/L) & $1.90 \pm 0.10$ & $6.90 \pm 0.10$ & $1.20 \pm 0.10$ & $1.50 \pm 0.20$ & 500 \\
\hline Phosphate (mg/L) & $0.10 \pm 0.00$ & $1.40 \pm 0.20$ & $0.60 \pm 0.12$ & $0.40 \pm 0.10$ & - \\
\hline Temperature ( $\left.{ }^{\circ} \mathrm{C}\right)$ & 25 & 26 & 25 & 27 & - \\
\hline
\end{tabular}

Values are mean $\pm \mathrm{SD}$ of 3 determinations of the parameters.

\subsection{Heavy metal levels in groundwater}

The experimental data statistics obtained for the heavy metal content of the groundwater samples are as shown in Table 2. Cr ranged from 0.20 to $0.80 \mathrm{mg} / \mathrm{L}$. High levels of $\mathrm{Pb}$ ranging from 1.71-3.20 mg/L were recorded. The level of Cd ranged from $0.02-0.10 \mathrm{mg} / \mathrm{L}$. The Fe content diverged from $2.19-11.40 \mathrm{mg} / \mathrm{L}$. The level of Manganese fluctuated between 0.05 to $0.50 \mathrm{mg} / \mathrm{L}$. The Nickel diverged from $0.04-0.14 \mathrm{mg} / \mathrm{L}$. The Cobalt content alternated from $0.22-0.40 \mathrm{mg} / \mathrm{L}$. The analysis of variance results revealed that $\mathrm{Ni}, \mathrm{Pb}$, and $\mathrm{Co}$ did not show a significant difference $(P<0.05)$. However, $\mathrm{Cd}, \mathrm{Mn}, \mathrm{Cr}$, and Fe showed significant difference $(\mathrm{P}<0.05)$ within the study area. 
The relationship between parameters as well as their origin were evaluated using the Pearson- correlation. The correlation matrix for physicochemical parameters was shown in table 3 and for heavy metals in table 4 . A strong positive correlation was observed between COD and temperature $(r=0.976, p>0.05)$ while a strong negative correlation was observed between COD and $p H(r=-0.990, p>0.01)$ and DO and turbidity $(r=-0.988, p>0.05)$. The presence of strong positive correlation between the parameters predicates that they were influenced by same anthropogenic activities. However, strong negative correlation between the parameters showed the disparity in the activities that influenced them (Ibe et al., 2020).

Similarly, the presence of strong positive correlation between the heavy metals presupposes that the metals have same origin or that their presence may have being a consequence of similar human activities (Owamah, 2020).

Table 2: Statistics of heavy metal levels in groundwater

\begin{tabular}{|llllll|}
\hline Metal (mg/L) & U1 & U2 & U3 & U4 & WHO (2011) \\
\hline $\mathrm{Cr}$ & $0.20 \pm 0.10^{\mathrm{a}}$ & $0.80 \pm 0.11^{\mathrm{a}}$ & $0.22 \pm 0.14^{\mathrm{c}}$ & $0.44 \pm 0.04^{\mathrm{b}}$ & 0.05 \\
\hline $\mathrm{Pb}$ & $1.71 \pm 1.20^{\mathrm{a}}$ & $3.01 \pm 0.83^{\mathrm{a}}$ & $3.20 \pm 1.51^{\mathrm{a}}$ & $1.90 \pm 0.71^{\mathrm{a}}$ & 0.01 \\
\hline $\mathrm{Cd}$ & $0.03 \pm 0.00^{\mathrm{ab}}$ & $0.06 \pm 0.01^{\mathrm{c}}$ & $0.02 \pm 0.11^{\mathrm{a}}$ & $0.10 \pm 0.01^{\mathrm{bc}}$ & 0.003 \\
\hline $\mathrm{Fe}$ & $2.19 \pm 1.32^{\mathrm{a}}$ & $11.40 \pm 0.30^{\mathrm{c}}$ & $2.50 \pm 0.65^{\mathrm{a}}$ & $5.20 \pm 0.44^{\mathrm{b}}$ & - \\
\hline $\mathrm{Mn}$ & $0.10 \pm 0.01^{\mathrm{a}}$ & $0.20 \pm 0.05^{\mathrm{a}}$ & $0.50 \pm 0.10^{\mathrm{b}}$ & $0.05 \pm 0.10^{\mathrm{a}}$ & 0.05 \\
\hline $\mathrm{Ni}$ & $0.04 \pm 0.10^{\mathrm{a}}$ & $0.11 \pm 0.05^{\mathrm{a}}$ & $0.14 \pm 0.10^{\mathrm{a}}$ & $0.06 \pm 0.05^{\mathrm{a}}$ & 0.02 \\
\hline $\mathrm{Co}$ & $0.40 \pm 0.33^{\mathrm{a}}$ & $0.22 \pm 0.14^{\mathrm{a}}$ & $0.35 \pm 0.04^{\mathrm{a}}$ & $0.40 \pm 0.20^{\mathrm{a}}$ & - \\
\hline
\end{tabular}

Values are mean \pm SD of 3 determinations of the heavy metal concentration of the groundwater samples. Mean value in the same row with the same superscript letters are not significantly different $(p>0.05)$.

Table 3: Correlation between physicochemical parameters in groundwater

\begin{tabular}{|c|c|c|c|c|c|c|c|c|c|c|}
\hline Parameters & $\mathrm{pH}$ & $\mathrm{EC}$ & DO & BOD & COD & Turbidity & Nitrate & Sulphate & Phosphate & Temperature \\
\hline $\mathrm{Ph}$ & 1.000 & & & & & & & & & \\
\hline EC & 0.652 & 1.000 & & & & & & & & \\
\hline DO & -0.581 & 0.232 & 1.000 & & & & & & & \\
\hline BOD & 0.000 & 0.740 & 0.763 & 1.000 & & & & & & \\
\hline COD & $-0.990^{* *}$ & -0.716 & 0.489 & -0.068 & 1.000 & & & & & \\
\hline Turbidity & 0.538 & -0.288 & $-0.988^{*}$ & -0.829 & -0.457 & 1.000 & & & & \\
\hline Nitrate & -0.440 & -0.837 & -0.271 & -0.824 & 0.448 & 0.392 & 1.000 & & & \\
\hline Sulphate & 0.182 & -0.346 & -0.683 & -0.429 & -0.042 & 0.587 & -0.043 & 1.000 & & \\
\hline Phosphate & 0.073 & -0.642 & -0.821 & -0.798 & 0.055 & 0.792 & 0.411 & 0.885 & 1.000 & \\
\hline Temperature & -0.938 & -0.734 & 0.381 & -0.091 & $0.976^{*}$ & -0.379 & 0.368 & 0.164 & 0.203 & 1.000 \\
\hline \multicolumn{11}{|c|}{ **. Correlation is significant at the 0.01 level (2-tailed). } \\
\hline *. Correlation & signific & at the 0 . & 5 level $(2$ & ailed). & & & & & & \\
\hline
\end{tabular}

Table 4: Correlation between heavy metals in groundwater 


\begin{tabular}{|llllllll|}
\hline & $\mathrm{Cr}$ & $\mathrm{Pb}$ & $\mathrm{Cd}$ & $\mathrm{Fe}$ & $\mathrm{Mn}$ & $\mathrm{Ni}$ & $\mathrm{Co}$ \\
\hline Metal & & & & & & & \\
\hline $\mathrm{Cr}$ & 1.000 & & & & & \\
\hline $\mathrm{Pb}$ & 0.341 & 1.000 & & & & \\
\hline $\mathrm{Cd}$ & 0.891 & -0.124 & 1.000 & & & \\
\hline $\mathrm{Fe}$ & $0.996^{* *}$ & 0.392 & 0.861 & 1.000 & & \\
\hline $\mathrm{Mn}$ & -0.197 & 0.836 & -0.611 & -0.155 & 1.000 & & \\
\hline $\mathrm{Ni}$ & 0.179 & $0.985^{*}$ & -0.287 & 0.238 & 0.897 & 1.000 & \\
\hline $\mathrm{Co}$ & -0.870 & -0.600 & -0.625 & -0.910 & -0.065 & -0.494 & 1.000 \\
\hline **. Correlation is significant at the 0.01 level (2-tailed). & & \\
\hline \multicolumn{7}{|c}{} \\
\hline
\end{tabular}

*. Correlation is significant at the 0.05 level (2-tailed).

\section{Discussion}

\subsection{Physicochemical levels in groundwater}

The $\mathrm{pH}$ of water is a reflection of its alkalinity or acidity. The values obtained in this study are lower than the range of 4.35 to 9.42 reported for groundwater in Sagamu and Ota areas of Ogun State, Nigeria (Zacchaeus et al., 2020). Generally, the samples were slightly acidic and alkaline among the sites. $\mathrm{pH}$ does not have a direct health implication on human beings but its indirect effects cannot be ignored (Adekunle et al., 2004). All pH values except U4 were within the specified levels of WHO (2011). This exception may be connected with the geology of the study area (Addo et al., 2016). Electrical conductivity (EC) is the degree of the number of dissolved salts in water. It gives the sum of ionic conductance of all ionic factors of water including dissolved nutrients and micronutrients (Mwajuwa, 2010; Das et al, 2013). This is lower than the range of $130 \mu \mathrm{S} / \mathrm{cm}$ to $940 \mu \mathrm{S} / \mathrm{cm}$ obtained for groundwater sources in Ogbomosho, Oyo State, Nigeria (Bamigboye et al, 2020). The presence of high dissolved salts in water can affect the productivity and properties of a soil when it is used for irrigation (Rezaei et al, 2020). The EC results gotten in the study are within the specified levels of WHO (2011). DO is a significant pointer of the stability of an aquatic ecosystem as low DO values cannot sustain aquatic life (Ezemonye et al, 2019). The DO values obtained in this study was lower than the specified levels of $5 \mathrm{mg} / \mathrm{L}$ specified by WHO (2011). BOD is an indication of the organic pollution load of water (Owamah, 2020). High BOD values reflect the presence of organic pollution. This is within the WHO (2011) specified limit of $6 \mathrm{mg} / \mathrm{L}$ and indicates the absence of organic pollution in the groundwater studied. The values obtained in this study was lower than the range of 4.00 to $6.80 \mathrm{mg} / \mathrm{L}$ obtained for groundwater in the Niger Delta region of Nigeria (Owamah, 2020). The mean turbidity values ranged from 5.70 to 7.40 NTU. This is above the WHO (2011) specified value of 5 NTU. This high turbidity values may be connected to anthropogenic activities, microorganisms, colloidal organic matter and suspended particles (Khan et al., 2019; Alexander et al., 2019). The turbidity values obtained in this study are not in agreement with the findings of Bamigboye et al., (2020) where values lower than 5 NTU were obtained. Nitrate values in the range of $3.40 \mathrm{mg} / \mathrm{L}$ to $18.90 \mathrm{mg} / \mathrm{L}$ were obtained in this study. A high concentration of nitrate in water is hazardous to human health and can harm the respiratory system (Singh and Hussain, 2016; Sudarshan et al., 2019). Sulphate values ranged from $1.20 \mathrm{mg} / \mathrm{L}$ to $6.90 \mathrm{mg} / \mathrm{L}$. This is lower than the specified value of $50 \mathrm{mg} / \mathrm{L}$ (WHO, 2011). The low sulphate concentration could be attributed to the minimizing effects of aquifers which prevent sulphide oxidation (Tirkey et al., 2017). The phosphate content varied from $0.10 \mathrm{mg} / \mathrm{L}$ to $1.40 \mathrm{mg} / \mathrm{L}$. The presence of phosphate could be associated with the use of fertilizers by the farmers (Egbueri, 2018). There is no health-related effect associated with phosphate in water (Owamah, 2020). Temperature is a criterion of the level of hotness or coldness of water. It ranged from 25 to $27^{\circ} \mathrm{C}$. There is no specified value for temperature but it exceeded room temperature of $20-22^{\circ} \mathrm{C}$. There is no reported health implication for temperatures above the ambient level. All the physicochemical parameters studied did not show a significant difference $(P<0.05)$ except for COD that varied significantly $(P<0.05)$ within the study area. 
The Cr value obtained in this study exceeded the WHO (2011) specified level of $0.05 \mathrm{mg} / \mathrm{L}$. Water containing $\mathrm{Cr}$ exceeding $0.05 \mathrm{mg} / \mathrm{L}$ can induce gastrointestinal cancer (Ibe et al., 2020). Pb exceeded the WHO (2011) specified level of $0.01 \mathrm{mg} / \mathrm{L}$. The value obtained in this study is higher than the range of 0.00-0.04 mg/L obtained for groundwater in Owerri, Southeastern Nigeria (Ibe et al., 2020). The high level of $\mathrm{Pb}$ may be connected to inappropriate dumping of waste containing $\mathrm{Pb}$ within the vicinity of the groundwater (Oni and Hassan, 2013) and it can cause subencelophalopathic disorder (Sojobi, 2016). The level of Cd was above the WHO (2011) specified level of $0.003 \mathrm{mg} / \mathrm{L}$. the Cd levels obtained in this study were higher than the range of $0.002-0.029 \mathrm{mg} / \mathrm{L}$ obtained by Zachaeus et al (2020). Cd ranks third in the list of heavy metals frequently reported in water and it has raised serious concerns because of its carcinogenic nature (Dahunsi et al., 2012; ATSDR, 2015). Ingestion of cadmium contaminated water has been reported to cause renal failure, anemia, hypertension, cardiovascular diseases, kidney diseases, lung damages and fragile bones (Bawaskar et al., 2010; Gobe and Crane, 2010; ATSDR, 2015; Benard, 2008). The Fe content was higher than the range of 0.02-02.01 mg/L reported by Zacchaeus et al (2020). Iron is a very useful component of the human diet (Zacchaeus et al., 2020). The high iron level may be a consequence of pipe corrosion (Prakash and Somasshekar, 2006). There is no specified health limit for iron. All the values of manganese obtained in this study were above the WHO (2011) specified value of $0.05 \mathrm{mg} / \mathrm{L}$ except for U4. The Mn content obtained in this study is lower than the range of 0.002-1.21 mg/L obtained by Aladejana and Talabi (2013). Manganese is vital to the human body but when present in high levels it can become harmful to the body (Zacchaeus et al., 2020). The Nickel level exceeded the WHO specified value of $0.02 \mathrm{mg} / \mathrm{L}$. The values of $\mathrm{Ni}$ obtained were lower the variation of 0.2-12.9 mg/L recorded by Aladejana and Talabi (2013). The situation of groundwater around a dumpsite could account for the presence of Ni (Elumalai et al., 2017). Ni plays a crucial role in the biological activities of microorganisms and plants (Asare- Donkor et al., 2016). However, at high levels, Ni is toxic (Kumar et al., 2016). The Cobalt content was lower than the range of $0.273-0.830$ reported by Sridlar et al (2017). The presence of Co may have resulted from dumpsite leachate in the study area (Purushotham et al., 2013). It is useful to the human body but harmful at high amounts (ASTDR, 2004). The analysis of variance results revealed that $\mathrm{Ni}, \mathrm{Pb}$, and $\mathrm{Co}$ did not show a significant difference $(\mathrm{P}<0.05)$. However, $\mathrm{Cd}, \mathrm{Mn}, \mathrm{Cr}$, and $\mathrm{Fe}$ showed significant difference $(P<0.05)$ within the study area.

\subsection{Assessment of the origin of physicochemical parameters and heavy metal using correlation}

A strong positive correlation was observed between COD and temperature $(r=0.976, p>0.05)$ while a strong negative correlation was observed between COD and $\mathrm{pH}(r=-0.990, p>0.01)$ and $\mathrm{DO}$ and turbidity $(r=-0.988, p>0.05)$. The presence of strong positive correlation between the parameters predicates that they were influenced by same anthropogenic activities. However, strong negative correlation between the parameters showed the disparity in the activities that influenced them (Ibe et al., 2020).

Similarly, the presence of strong positive correlation between the heavy metals presupposes that the metals have same origin or that their presence may have being a consequence of similar human activities (Owamah, 2020).

\section{Conclusion}

A precise appraisal of the physicochemical parameters and heavy metal content of some groundwater sources in the vicinity of the liquid waste treatment plant of Ahmadu Bello University Teaching Hospital, Shika was carried out. All the physicochemical parameters studied were within the WHO specified limits except for DO and turbidity. Heavy metals were found in the all the groundwater sources that were studied. However, the concentration of some heavy metals exceeded the specified limits recommended by the World Health Organization (WHO). The heavy metal presence in the groundwater sources may be connected to human activities such as waste disposal containing these metals around the groundwater sources and liquid waste from the hospital which can seep into the wells. It can be inferred from this study that water from these hand-dug wells are not safe for drinking. It is recommended that wells be sited away from dumpsites and waste treatment plants. Effluents from waste treatment plants should also be properly treated before their subsequent discharge into the environment. This study generated a baseline data that will be useful in monitoring heavy metal pollution.

\section{Declarations}

- ETHICS approval and consent to participate (Not applicable in this section)

- Consent for Publication (Not applicable in this section)

- Availability of data and material (It has been reported and cited in the methodology section of the manuscript)

- Competing interests (Not applicable in this section)

Page 6/10 
- Funding (None)

- Author's contributions (EAA did the conception and design of the work. SEA did analysis of data. LRM drafted the manuscript. OOF and SIRO revised the manuscript. All authors have read and approved the manuscript.)

- Acknowledgement (None)

- Authors' information (Department of Scientific and Industrial Research, National Research Institute for Chemical Technology, Zaria, Nigeria. Email: abakpa30@gmail.com, Tel: +2348036417894)

\section{Abbreviations}

Not applicable in this section

\section{References}

Abubakar, I.R., 2018. Exploring the determinants of open defecation in Nigeria using demographic and health survey data. Sci. Total Environ. 637-638, 1455-1465.

Owamah, H.I., 2020. A comprehensive assessment of groundwater quality for drinking water purpose in a Nigerian rural Niger delta community. Groundwater for Sustainable Development 10, 1-13

WHO/UNICEF, 2015. World Health Organization (WHO) and United Nations Children's Fund (UNECEF), Progress on Sanitation and Drinking Water e 2015 Update and MDG Assessment, vol. 2015. WHO, Switzerland. Available.

http://www.unicef.org/publications/index_82419.html.

Abubakar, I.R., 2019. Factors influencing household access to drinking water in Nigeria. Util. Policy 58, 40-51.

Bamigboye, C.O., Amao, J.A., Ayodele, T.A., Adebayo, A.S., Ogunleke, J.D., Abass, T.B., Oyedare, T.A., Adetutu, T.J., Adeeyo, A.O., Oyedemi, A.A. 2020. An appraisal of the drinking water quality of groundwater sources in Ogbomoso, Oyo state, Nigeria. Groundwater for Sustainable Development 11, 1-8.

Ibe, F.C., Opara, A.I., Ibe, B.O. 2020. Application of pollution risk evaluation models in groundwater systems in the vicinity of automobile scrap markets in Owerri municipal and environs, southeastern Nigeria. Scientific Africa 8, 1-21.

Oyelami, A.C., Aladejana, J.A., Agbede, O.O., 2013. Assessment of the impact of open waste dumpsites on groundwater quality: a case study of the Onibu-Eja dumpsite, Southwestern Nigeria. Procedia Earth Planet. Sci. 7, 648-651.

WHO, UNICEF RADWQ, 2012. Rapid assessment of drinking-water quality (RADWQ): a handbook for implementation. In: Geneva, Switzerland, World Health Organization (WHO); New York, USA, United Nations Children's Fund (UNICEF).

WHO, 2012. World Health Organization (WHO). Global Burden of Disease. WHO Press, Geneva, Switzerland.

National Population Commission of Nigeria (NPC), 2017. http://www.informationng.com/tag/national-population-commission.

Dahunsi, S.O., Owamah, H.I., Ayandiran, T.A., Oranusi, S.U., 2014. Drinking Water quality and public health of selected towns in southwestern Nigeria. Water Qual. Expo. Health.

Sojobi, S.O., 2016. Evaluation of groundwater quality in a rural community in North Central of Nigeria. Environ. Monit. Assess. 20 (188), 192.

American Public Health Association (APHA), 2012. Standard Methods for Examination of Water and Waste-Water, twenty-second ed. American Public Health Association, Washington DC.

Adekunle, I.M., Adetunji, M.T., Gbadebo, A.M., Banjoko, O.B., 2004. Assessment of groundwater quality in a typical rural settlement in southwest Nigeria. Int. J. Environ. Res. Publ. Health 4, 307-318.

World Health Organization (WHO) 2011. WHO Guidelines for drinking water quality, $4^{\text {th }}$ ed. World Health Organization, Geneva. pp. 219229.

Page $7 / 10$ 
Addo M, Oti-Boateng W, Obiri-Danso K., 2016. Bacteriological quality and metal levels of boreholes and hand-dug well within the Golden Star Wassa mining areas in Ghana. African J Microbiol Res, 10(17):584-90.

Mwajuma, J.J., 2010. Physico-Chemical and bacteriological quality of water, and antimicrobial susceptibility of pathogenic isolates from selected water sources in Samburu South. Phamacological Magazine 8-90.

Das, S., Patnaik, S.C., Sahu, H.K., Chakraborty, A., Sudarshan, M., Thatoi, H.N., 2013. Heavy metal contamination, physico-chemical and microbial evaluation of water samples collected from chromite mine environment of Sukinda, India. Trans. Nonferrous Metals Soc. China 23 (2), 484-493.

Rezaei, A., Hassani, H., Tziritis, E., Mousavi, S.B.F., Jabbari, N., 2020. Hydrochemical Characterization and Evaluation of Groundwater Quality in Dalgan Basin, SE Iran. Groundwater for Sustainable Development, p. 100353.

Ezemonye, L.I., Adebayo, P.O., Alex A. Enuneku, A.A., Isioma Tongoa, I., Ogbomida, E. 2019. Potential health risk consequences of heavy metal concentrations in surface water, shrimp (Macrobrachium macrobrachion) and fish (Brycinus longipinnis) from Benin River, Nigeria. Toxicology Reports 6, 1-9.

Khan N, Hussain ST, Saboor A, Jamila N, Kim KS., 2019. Physicochemical investigation of the drinking water sources from Mardan, Khyber Pakhtunkhwa, Pakistan. Life Sci J.16(3).

Alexander P, Bwatanglang I, Daniel J., 2019. Assessment of Physicochemical and Bacteriological Parameters of Borehole and Hand Dug Well Water in Michika and Environs, Adamawa State, Nigeria. Microbiol Res J Int. 1-11.

Singh S, Hussian A. , 2016Water quality index development for groundwater quality assessment of Greater Noida sub-basin, Uttar Pradesh, India. Cogent Eng. 3(1):1177155.

Sudarshan P, Mahesh M, Ramachandra T., 2019. Assessment of seasonal variation in water quality and water quality index (WQI) of Hebbal Lake, Bangalore, India. Environ Ecol. 37(1B):309-17.

Tirkey P, Bhattacharya T, Chakraborty S, Baraik S., 2017. Assessment of groundwater quality and associated health risks: a case study of Ranchi city, Jharkhand, India. Groundwater Sustainable Dev. 5:85-100.

Egbueri, J.C., 2018. Assessment of the quality of groundwaters proximal to dumpsites in Awka and Nnewi metropolises: a comparative approach. Int J Energ Water Res https://doi.org/10.1007/s42108-018-0004-1.

Oni, A.A., Hassan, A.T., 2013. Groundwater quality in the vicinity of Aba-Eku dumpsite, Ibadan, Southwest, Nigeria. A detailed report. Ethiop. J. Environ. Stud. Manag. 6 (6), 589-600.

Dahunsi, S.O., Oranusi, S.U., Ishola, R.O., 2012. Bioaccumulation pattern of cadmium and lead in the head capsule and body muscle of Clariasgariepinus [Burchell, 1822] exposed to paint emulsion effluent. Res. J. Environ. Earth Sci. 4 (2), 166-170.

ATSDR (Agency for Toxic Substances and Disease Registry), 2015. ToxProfiles. Toxic Substances Portal.

Bawaskar, H.S., Bawaskar, P.H., Bawaskar, P.H., 2010. Chronic renal failure associated with heavy metal contamination of drinking water: a clinical report from a small village in Maharashtra. J. Clin. Toxicol. 48 (7), 768.

Gobe, G., Crane, D., 2010. Mitochondria, reactive oxygen species and cadmium toxicity in the kidney. Toxicol. Lett. $198,49-55$.

Bernard, A, 2008. Cadmium and its adverse on human health. Ind. J. Med. Res. 128 (4), 557-564.

Prakash, K.L., Somasshekar, R.K., 2006. Groundwater quality - assessment on Anekal Taluk, Bangalore urban district, India. J. Environ. Biol. 9, 12-29.

Aladejana, J.A., Talabi, A.O., 2013. Assessment of groundwater quality in Abeokuta southwestern, Nigeria. Int. J. Eng. Sci. 2 (6), $21-31$ online at: www.researchinventy.com.

Elumalai, V., Brindha, K., Lakshmanan, E., 2017. Human exposure risk assessment due to heavy metals in groundwater by pollution index and multivariate statistical methods: a case study from South Africa. Water 9, 234. https://doi.org/10.3390/w9040234.

Page $8 / 10$ 
Asare-Donkor, N.K., Boadu, T.A., Adimado, A.A., 2016. Evaluation of groundwater and surface water quality and human risk assessment for trace metals in human settlements around the Bosomtwe Crater Lake in Ghana, Springer Plus 5 (1812) 1-19.

Kumar, M., Subhash, S.C., Jha, M.K., 2016. Heavy metals concentration assessment in groundwater and general public health aspects around granite mining sites of Laxman Pura, U.P., Jhansi, India, Int. Res. J. Environ. Sci. 5 (1), 1-6.

Sridhar, S.G.D., Sakthivel, A.M., Sangunathan, U., M. Balasubramanian, M., Jenefer, S., M. Mohamed Rafik, M., Kanagaraj, G., 2017. Heavy metal concentration in groundwater from Besant Nagar to Sathankuppam, South Chennai, Tamil Nadu, India. Appl Water Sci. 7:4651-4662.

Purushotham. D., Rashid, M., Lone, M.A., Rao, A.N., Ahmed, S., Nagaiah, E., Dar, F.A., 2013. Environmental impact assessment of air and heavy metal concentration in groundwater of Maheshwaram watershed, Ranga Reddy district, Andhra Pradesh. J Geol Soc India 81(3):385-396

\section{Figures}

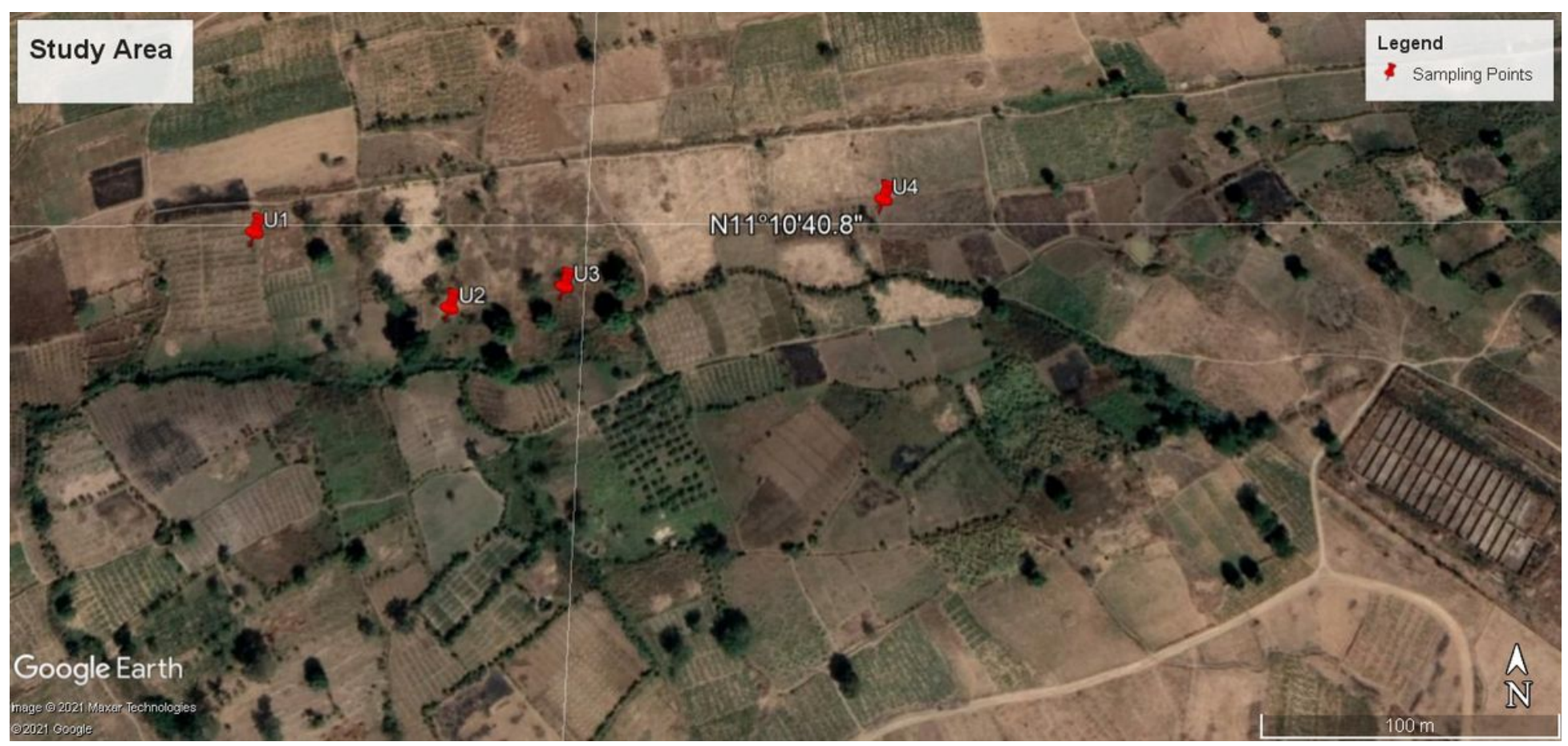

\section{Figure 1}

A map of the study area. 


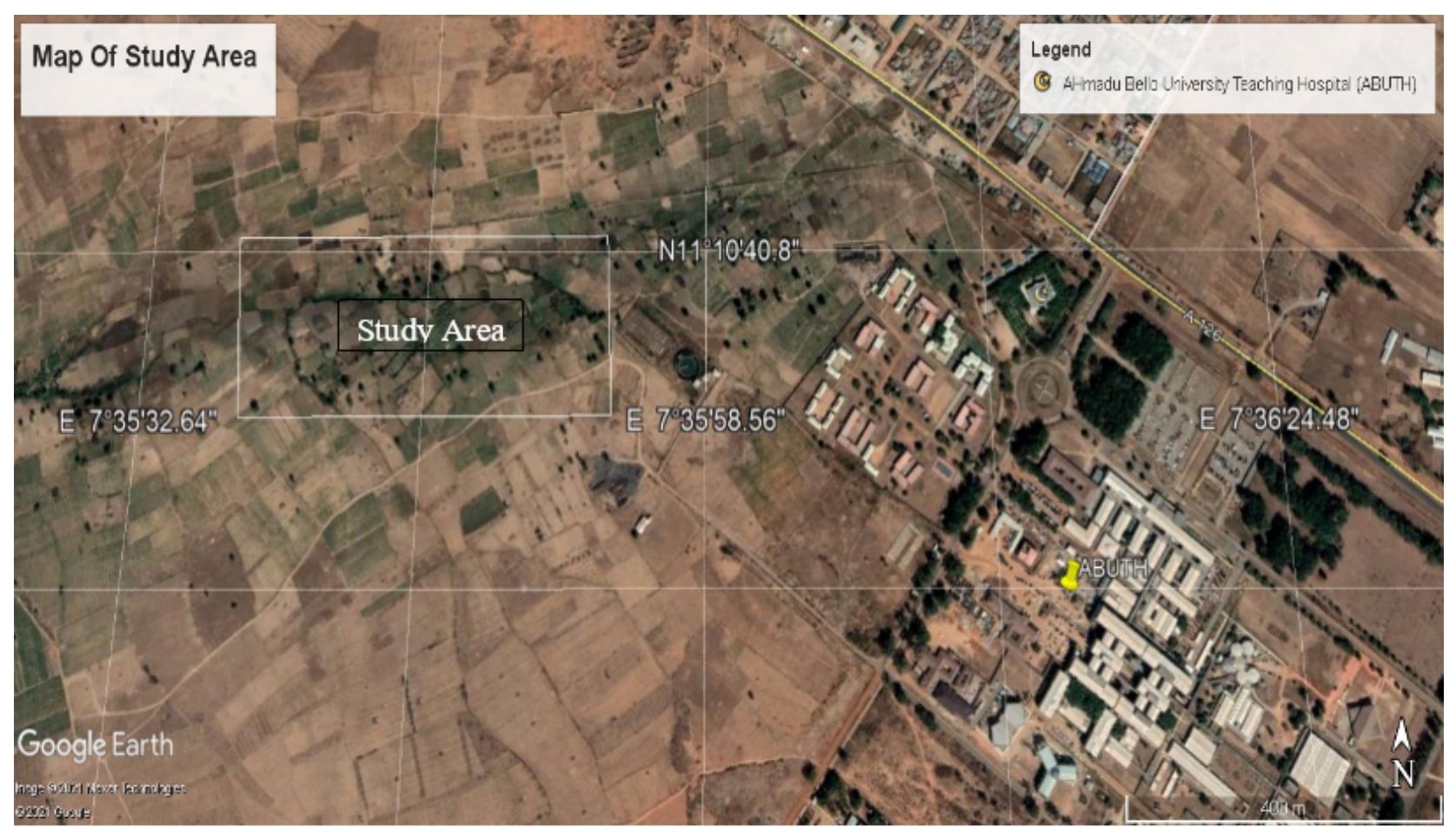

\section{Figure 2}

Study Area showing the Sampling Points 